\title{
Three Virus-resistant Snap Bean Germplasm Lines, USWA-64, USWA-67, and USWA-68
}

\author{
An N. Hang ${ }^{1}$ \\ Crop and Soil Sciences, Irrigated Agriculture Research and Extension Center, \\ Washington State University, Prosser, WA 99350-9587
}

Matt J. Silbernagel $^{2}$ and Phillip N. Miklas ${ }^{3}$

Vegetable and Forage Crops Production Research, U.S. Department of Agriculture, Agricultural Research Services, Prosser, WA 99350-9587

Additional index words. Phaseolus vulgaris, bean common mosaic virus, curly top virus

Three snap bean (Phaseolus vulgaris L.) breeding lines, USWA-64, USWA-67, and USWA-68, were jointly released in Nov. 1996 by the U.S. Dept. of Agriculture-Agriculture Research Service (USDA-ARS) and the Agricultural Research Centers of Washington State Univ., the Univ. of Idaho, and Oregon State Univ. These germplasm lines possess the dominant $I$ gene conditioning resistance to bean common mosaic virus (BCMV) and complete resistance to curly top virus (CTV), presumed to be due to two dominant epistatic genes (unpublished data). These lines produce a high yield of well-distributed green pods on an erect, bushy plant. USWA-64, USWA-67, and USWA-68 were developed to combine resistance to BCMV and CTV for a largesieved (6-sieve: $>27 / 64$-inch or 1.07-cm diameter) blue lake home garden type (USWA64), small-sieved (4-sieve: $24 / 64$ inch or 0.953 $\mathrm{cm})$ blue lake processing type (USWA-67), and a medium-sieved (5-sieve: 27/64 inch or $1.07 \mathrm{~cm}$ ) fresh-market type (USWA-68) for production in the arid western states.

\section{Origin}

The home garden type USWA- 64 is an $\mathrm{F}_{12}$ bulk population from a single plant selection in the $\mathrm{F}_{5}$ generation from the cross (NVRS$196 \times$ OSU-4091-3) x (5BP-3 x Valliant). NVRS-196 is a cold-tolerant germplasm line from the National Vegetable Research Station, Wellesbourne, England. OSU-4091-3 is a large-sieved, bush blue lake developed by James Baggett at Oregon State Univ. 5BP-3 is a small-sieved germplasm release with resistance to BCMV and CTV developed by Silbernagel (1979). Valliant is a small-sieved, multiple disease resistant, bush snap bean developed by H. Bannerot of the Institut Nationale

Received for publication 19 Mar. 1998. Accepted for publication 16 Nov. 1998. The cost of publishing this paper was defrayed in part by the payment of page charges. Under postal regulations, this paper therefore must be hereby marked advertisement solely to indicate this fact.

${ }^{1}$ Associate Agronomist; to whom reprint requests should be addressed (ahang@tricity.wsu.edu).

${ }^{2}$ Research Pathologist (retired).

${ }^{3}$ Research Geneticist.
delaRecherche Agronomique, Versailles, France. Valliant possesses the dominant $I$ gene conditioningresistance to BCMV,the Co-2(Are) gene for resistance to anthracnose [Colletotrichum lindemuthianum (Sacc.\& Magnus) Lambs.\& Scrib.] and an unknown gene for halo blight [Pseudomonas phaseolicola (Burkh.) Dows.] resistance, but is susceptible to CTV. Besides dominant $I$ gene, USWA-64 possesses the recessive $b c-1$, which, in combination with $I$, imparts partial protection to the hypersensitive necrosis syndrome due to strains of bean common mosaic necrosis virus (BCMNV). The line is resistant to all endemic strains of BCMV in the United States, including the NL8 strain of BCMNV (Silbernagel, 1981).

USWA-67 is an $\mathrm{F}_{25}$ bulk population from a single plant selection in the $\mathrm{F}_{20}$ generation from the cross (OSU-1604 x 5BP-7) x RH-13. OSU-1604 is a large-sieved, bush blue lake line developed by William A. Frazier at Oregon State Univ. 5BP-7 is a large-sieved, bush blue lake, heat tolerant, BCMV- and CTVresistant, germplasm line (Silbernagel, 1979). RH-13 is a small-sieved, European type, bush snap bean developed by $\mathrm{H}$. Bannerot. Besides dominant $I$ gene resistance to BCMV and complete resistance to CTV, USWA-67 is resistant to anthracnose $(\mathrm{Co}-2)$ and to all known strains of halo blight in the United States. USWA-67 was derived from the mass selection for small pod size during each generation (Silbernagel, 1979).

USWA-68 is an $\mathrm{F}_{12}$ bulk population from a single plant selection in the $\mathrm{F}_{5}$ generation from the cross BARC-1 x [(GN-31 x D-9) x OSU10183]. BARC-1 is a rust-resistant, bush snap bean germplasm line developed by J. Meiners, USDA-ARS. GN-31 is a vine-type great northern developed by L. Dean, Univ. of Idaho. Breeding line D-9 is a USDA-ARS bush snap bean with CTV and BCMV resistance developed by D.W. Burke. OSU-10183 is an upright bush blue lake breeding line developed by William A. Frazier, Oregon State Univ. Besides possessing two dominant genes for resistance to $\mathrm{CTV}$ and the $I$ and $b c-1$ gene combination for resistance to BCMV, USWA68 is resistant to some strains of rust (J.R. Stavely, USDA-ARS, Beltsville, Md., personal communication).
The outstanding features of USWA-64 are early maturity, excellent-quality blue lake flavored pods, and uniquely crinkled leaves (bush blue lakes represent a market class characterized primarily by a distinctively flavored pod). The dark green pods are smooth, straight, round, $\approx 14.6 \mathrm{~cm}$ long, and stringless. They remain firm and flavorful with small seed size, even when the pods reach a relatively large sieve size (sieve 5-6). If pods are harvested frequently as they mature, the plant keeps blooming and produces more pods over a period of several weeks. The medium- to largesized, dark green, glossy leaves have an unusually shortened midrib, which causes the leaves to appear very crinkled. Since the parental lines do not have crinkled leaves, this characteristic may be a rare mutant and may be a useful marker for genetic studies. The plant habit is upright but the top of the canopy is relatively open, allowing for easy access to the pods, which should be useful in a home garden variety.

The USWA-67 plant habit is an upright bush with a narrow profile. Pods are borne high on the plant, are medium to dark green, smooth, straight, round to slightly heart-shaped, $\approx 11.25 \pm 0.75 \mathrm{~cm}$ long, and are very tender in the 3-sieve and early 4-sieve stage (Sibernagel and Drake, 1978).

The USWA-68 plant habit is an upright bush with pods borne high on the plant and a concentrated harvest maturity. Pods are medium green, straight, round and $\approx 12.0 \pm 0.5 \mathrm{~cm}$ long, and reach peak maturity when in the 4sieve to early 5 -sieve size. Pods have a densely pubescent surface and cling to a cotton shirt, which is one of the criteria used by buyers of shipping-type beans. The hairy surface is less prone to wind scarring and, along with a slightly fibrous pod wall, helps prevent shrinkage during shipping and marketing.

\section{Availability}

A limited quantity of seed of USWA-64, USWA-67, and USWA-68 is available from Dr. Phillip N. Miklas, Vegetable and Forage Crop Production Research Unit, USDA-ARS, 24106 N. Bunn Road, Prosser, WA 993509687. Appropriate recognition must be made if this germplasm contributes to the development of a new breeding line or cultivar. Seeds of these releases will be deposited in the National Plant Germplasm System (National Seed Storage Lab, USDA-ARS, Fort Collins, Colo.).

\section{Literature Cited}

Silbernagel, M.J. 1979. Release of multiple disease resistant germplasm ARS lines 6BP-5, 6BP-6 and 5BP-7. Annu. Rpt. Bean Improv. Coop. 22:37-41.

Silbernagel, M.J. 1981. Inheritance of resistance to the NL-8 and NY-15 strains of bean common mosaic virus. Phytopathology 71:1007 (Abstr.).

Silbernagel, M.J. and S.R. Drake. 1978. Seed index, an estimate of snap bean quality. J. Amer. Soc. Hort. Sci. 103:257-260. 